\title{
Pharmacognostic evaluation of Bergenia ciliata (Haw.) Sternb
}

\author{
Shafqat Ali Khan ${ }^{1 *}$, Ghulam Dastagir², Barkatullah ${ }^{1}$, Sami Ullah², Izhar \\ Ahmad ${ }^{1}$ and Usman $\mathrm{Ali}^{3}$ \\ 1. Department of Botany Islamia College, Peshawar-Pakistan \\ 2. Department of Botany University of Peshawar-Pakistan \\ 3. Centre of Plant Biodiversity University of Peshawar-Pakistan \\ *Corresponding author's email: shafqatbotany3@gmail.com \\ Citation \\ Shafqat Ali Khan, Ghulam Dastagir, Barkatullah, Sami Ullah, Izhar Ahmad and Usman Ali. Pharmacognostic \\ evaluation of Bergenia ciliata (Haw.) Sternb. Pure and Applied Biology. Vol. 6, Issue 2, pp762-775. \\ http://dx.doi.org/10.19045/bspab.2017.60081
}

\begin{tabular}{llll}
\hline \hline Received: 08/02/2017 & Revised: 17/05/2017 & Accepted: 28/05/2017 & Online First: 15/06/2017 \\
\hline
\end{tabular}

\section{Abstract}

The present study was conducted to investigate the Bergenia ciliata (Haw.) Sternb. (Family: Saxifragaceae) for pharmacognostic study including macroscopical and microscopical observations, leaf surface features, Scanning Electron Microscopy and Fluorescence characters. The macroscopy revealed that rhizome was brown in color, hard in fracture, pleasant in odor and astringent in taste. Leaf was cordate, green in color and indistinct in taste and odour, while microscopy of rhizome and leaf showed typical dicot histological differentiation. Leaf was amphistomatic having anomocytic stomata on both the epidermises. The quantitative leaf study

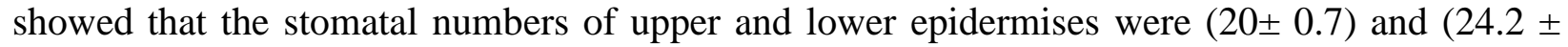
2.7) (average \pm SEM), while stomatal index was $(15.6 \pm 2.6)$ and $(27.4 \pm 3.9)$ respectively. Vein islet and vein termination number was $(20.6 \pm 4.09$ and $26.6 \pm 5.01)$, while palisade ratio remained $(12.3 \pm 3.71)$. SEM of the powder showed non-glandular trichomes, spiral vessels, parenchymatous tissues and fragments of epidermis with anomocytic stomata. Fluorescence study indicates different shadows of colors like brown, black, greenish, yellowish, red, brown, dark black, pink etc. that revealed the presence of different fluorescent chemical compounds. The current research was done for the first time on Bergenia and might be beneficial for its accurate identification, standardization and will give a base for its pharmacognistic applications.

Keywords: Bergenia ciliata; Pharmacognostic evaluation; Quantitative leaf microscopy; SEM; Fluorescence study

\section{Introduction}

Pharmacognosy is a multi-disciplinary science that covers collection, identification, physical, chemical, pharmacological and other biological evaluation of natural and crude plant and animal sources [1]. It indicates a particular understanding of systems of identification and assessment of natural drugs, which significantly reduces the unintentional and incorrect endorsements of traditional and natural plant products for pharmaceutical expenditures $[2,3]$ Medications derived from plant sources are thought to be much harmless and show an extraordinary effectiveness in the treatment of several disorders and have no side effect $[4,5]$. 
Physical and anatomical assessment is the primary stage to acquire information regarding diagnostic characters of crude drug, which are done by study of the cells, tissue and their structure, organization and cell substances [6, 7]. Along with morphological and histological features, the leaf surface quantitative study is also helpful in the systematic and taxonomic interpretations between various groups of phanerogams. Stomatal variations and diversity and other leaf features have extreme importance in plant taxonomy, systematics and may also help as effective tools in explaining taxonomic problems in the Angiosperm [8]. Fluorescence study is an essential parameter and a significant exhibition possessed by numerous chemical compounds present in plant material. The substances are converted to show fluorescence by dissolving and dipping in various chemical organic solvents like ethanol, methanol, $\mathrm{HCl}$ etc [8].

Bergenia ciliata (Haw.) Sternb. belong to Saxifragaceae commonly known as "Elephant ear" in English, "Pakhanbheid" in Urdu and "Makanpath" in Pashto is a herbaceous perennial plant grow up to $24 \mathrm{~cm}$ in height [9]. Bergenia grows in temperate Himalaya regions of the world up to the altitude of 3000-9000 feet [10]. In Pakistan, it has two species namely $B$. stracheyi and B. ciliata which are distributed in Galyat, Shangla, Swat, and Gilgit etc [11]. Therapeutically the rhizome used as astringents, stimulant, anti-acids and purgative. Its powder is given to pregnant women to increase lactation [12]. Cold decoction of leaves is use in kidney stones, cough, cold, and different brain and stomach disease. The leaf is also used in diarrhea, inflammation, GIT Chronic ulcers and various eye disease [13].

Materials and methods Collection and preservation

The fresh samples of $B$. ciliata was collected from Kotkay, district Shangla KP and taken to the Department of Botany, University of Peshawar and correctly identified by $\mathrm{Mr}$. Ghulam Jelani. Rhizome and leaf was selected for pharmacognostic study, cleaned, air dried and were grinded.

\section{Macroscopic observations}

Morphological and Macroscopic evaluations were carried out organoliptically through five senses that include Size, shape, color, taste, odour, appearance, texture and fracture surface in both fresh and dry states.

\section{Histological evaluation}

The histological and microscopic evaluations was carried out by making T.S of rhizome and leaf through hand sectioning mounting in potato slices carefully. The sections were observed under digital microscope fitted with camera and photographs were taken [14]. The micrometry of various types of cells was done using stage and ocular micrometer [15].

\section{Quantitative microscopy}

The quantitative leaf surface features including stomatal studies, vein islet number, vein termination number and palisade ratio were also carried out by peeling off both the epidermises from leaf of B. ciliata following methods of [15]. The stomatal types and other parameters were studied under microscope and also photographed.

\section{SEM of powder drug}

Powder drug study under Scanning Electron Microscope (SEM) was conducted in CRL, Department of Physics, University of Peshawar, Pakistan. Finally, the images were examined carefully and photographs of the identified tissues were printed [16].

\section{Fluorescence analysis}

Preliminary fluorescence study determined the presence of various chemical compounds in plant parts. The powder of rhizome and leaf of $B$. ciliata was dissolved in various solvents like Picric acid, Chloroform, Ferric 
chloride, Ether, Ethanol, HCL, Acetic acid, Iodine and $\mathrm{H}_{2} \mathrm{SO}_{4}$ etc. and observed under visible and UV short (254nm) and long (366nm) light and the changing colours were noticed and documented [17, 18].

\section{Results}

\section{Macroscopic observations}

The macroscopic features were carried out in both fresh and dry rhizome and leaf of $B$. ciliata which showed that the rhizome was average $7-20 \mathrm{~cm}$ in length, average $1-2.3 \mathrm{~cm}$ in width, cylindrical in shape, brown in colour, astringent in taste, pleasant in odour, flexible in texture and having fibrous fracture surface when fresh. On drying the rhizome become average $6-19 \mathrm{~cm}$ in length, $0.9-2 \mathrm{~cm}$ in width, irregular and dark brown in shape and color while indistinct in taste and odor (Table 1). The leaf macroscopy showed that it was $5-13 \mathrm{~cm}$ in average length, cordate in shape, dark green in colour when fresh, indistinct in taste and odor, soft in fracture, and even in texture surface in both fresh and dry conditions Table 1.

Table 1. Macroscopic features of various parts of Bergenia ciliata (Haw.) Sternb

\begin{tabular}{|c|l|c|c|c|c|}
\hline \multirow{2}{*}{ S.No } & \multirow{2}{*}{ Parameter studied } & \multicolumn{2}{|c|}{ Rhizome } & \multicolumn{2}{c|}{ Leaf } \\
\cline { 3 - 6 } & & Fresh & Dry & Fresh & Dry \\
\hline 1 & Length & $7-20 \mathrm{~cm}$ & $6-19 \mathrm{~cm}$ & $5-13 \mathrm{~cm}$ & $4.9-12.8 \mathrm{~cm}$ \\
\hline 2 & Width & $1-2.3 \mathrm{~cm}$ & $0.9-2 \mathrm{~cm}$ & -------- & ------- \\
\hline 3 & Shape & Cylindrical & Irregular & Cordate & Cordate \\
\hline 4 & Colour & Brown & Dark brown & Dark Green & Light green \\
\hline 5 & Taste & Astringent & Indistinct & Indistinct & Indistinct \\
\hline 6 & Odour & Pleasant & Indistinct & Indistinct & Indistinct \\
\hline 7 & Fracture & Flexible & Hard & Soft & Soft \\
\hline 8 & Fracture surface & Fibrous & Uneven & Even & Even \\
\hline
\end{tabular}

\section{Histological evaluation}

\section{Anatomy of rhizome of $B$. ciliata}

The T.S of the rhizome of B. ciliata appear circular in shape and surrounded by cork, which is consisted of irregular, in isodiametric thick walled brown color parenchyma cells with average $19 \mu$ in length and $10.4 \mu$ width (Table 2, Figure 1). The cork is followed by uniseriate isodiametric small celled epidermis with $19 \mu$ and $8 \mu$ length and width. Below the epidermis, the rhizome composed of single layered hypodermis whose cells average length and width was $17 \mu$ and $9 \mu$ respectively. The hypodermis was followed by a multilayer cortex having large and thin walled isodiametric spherical cells with $27 \mu$ and $16 \mu$ length and width. The rhizome showed conjoint vascular tissues which was collateral and open type; the phloem was towards the outer side while xylem was towards center. The average length and width of phloem sieve tube cells were $26 \mu$ and $15 \mu$. The xylem vessels were also clearly visible with $32 \mu$ and $16 \mu$ length and width. The center of rhizome was full with thin walled circular parenchymatous pith region with $38 \mu$ and $19 \mu$ average cell length and width (Table 2, Figure 1). 
Table 2. Histological measurements $(\mu)$ of various tissues of Bergenia ciliata (Haw.) Sternb

\begin{tabular}{|c|c|c|c|c|c|c|c|c|c|c|c|c|c|c|c|c|c|}
\hline S. & Plant & \multicolumn{16}{|c|}{ Cells and their size } \\
\hline \multirow{3}{*}{1} & \multirow{3}{*}{ Rhizome } & \multicolumn{2}{|l|}{ Cork } & \multicolumn{2}{|c|}{ Epidermis } & \multicolumn{2}{|c|}{ Hypodermis } & \multicolumn{2}{|l|}{ Cortex } & \multicolumn{2}{|c|}{ Pericycle } & \multicolumn{2}{|l|}{ Phloem } & \multicolumn{2}{|l|}{ Xylem } & \multicolumn{2}{|l|}{ Pith } \\
\hline & & Length & Width & Length & Width & Length & Width & Length & Width & Length & Width & Length & Width & Length & Width & Length & Width \\
\hline & & $19 \mu$ & $10.4 \mu$ & $19 \mu$ & $8 \mu$ & $17 \mu$ & $9 \mu$ & $17 \mu$ & $9 \mu$ & $20 \mu$ & $15 \mu$ & $26 \mu$ & $15 \mu$ & $32 \mu$ & $16 \mu$ & $38 \mu$ & $19 \mu$ \\
\hline \multirow{3}{*}{2} & \multirow{3}{*}{ Leaf } & \multicolumn{2}{|c|}{$\begin{array}{l}\text { Upper } \\
\text { Epidermis }\end{array}$} & \multicolumn{2}{|c|}{$\begin{array}{l}\text { Lower } \\
\text { Epidermis }\end{array}$} & \multicolumn{2}{|l|}{ Xylem } & \multicolumn{2}{|l|}{ Phloem } & \multicolumn{2}{|c|}{$\begin{array}{l}\text { Palisade } \\
\text { parenchhyma }\end{array}$} & \multicolumn{2}{|c|}{$\begin{array}{l}\text { Spongy } \\
\text { parenchhyma }\end{array}$} & \multicolumn{2}{|c|}{ Guard cells } & \multicolumn{2}{|l|}{ Stoma } \\
\hline & & Length & Width & Length & Width & Length & Width & Length & Width & Length & Width & Length & Width & Length & Width & Length & Width \\
\hline & & $26 \mu$ & $12 \mu$ & $30 \mu$ & $10 \mu$ & $19 \mu$ & $12 \mu$ & $29 \mu$ & $12 \mu$ & $19 \mu$ & $11 \mu$ & $20 \mu$ & $9 \mu$ & $34 \mu$ & $10 \mu$ & 26 & $8 \mu$ \\
\hline
\end{tabular}



Figure 1.Transvers Section of rhizome of $B$. ciliata 


\section{Anatomy of leaf of $B$. ciliata}

The TS of leaf of $B$. ciliata showed that it was enclosed by single layered compactly arranged rectangular shaped upper epidermis ( $26 \mu$ length and $12 \mu$ width) and lower epidermis with average length and width $26 \mu$ and $12 \mu$ (Table 2, Figure 2). Upper epidermis was covered by smooth cuticle. Through midrib the area below epidermises was occupied by parenchymatous region and in center composed of crescent shape collateral and closed vascular bundles in dispersed form. Phloem enclosed xylem. The length and width of xylem vessels was
$30 \mu$ and $10 \mu$ and phloem sieve cells was $29 \mu$ and $12 \mu$ (Table 2, Figure 2). The T.S through lamina occupied by upper and lower epidermis followed by palisade and spongy parenchyma respectively. Palisade was composed of compactly arranged cylindrical cells with average length and width $19 \mu$ and $11 \mu$, while spongy parenchyma possess irregular shaped cell with average length and width $20 \mu$ and $9 \mu$ respectively. Large area between the spongy mesophyll cells was consisted of large intercellular spaces (Table 2, Figure 2).

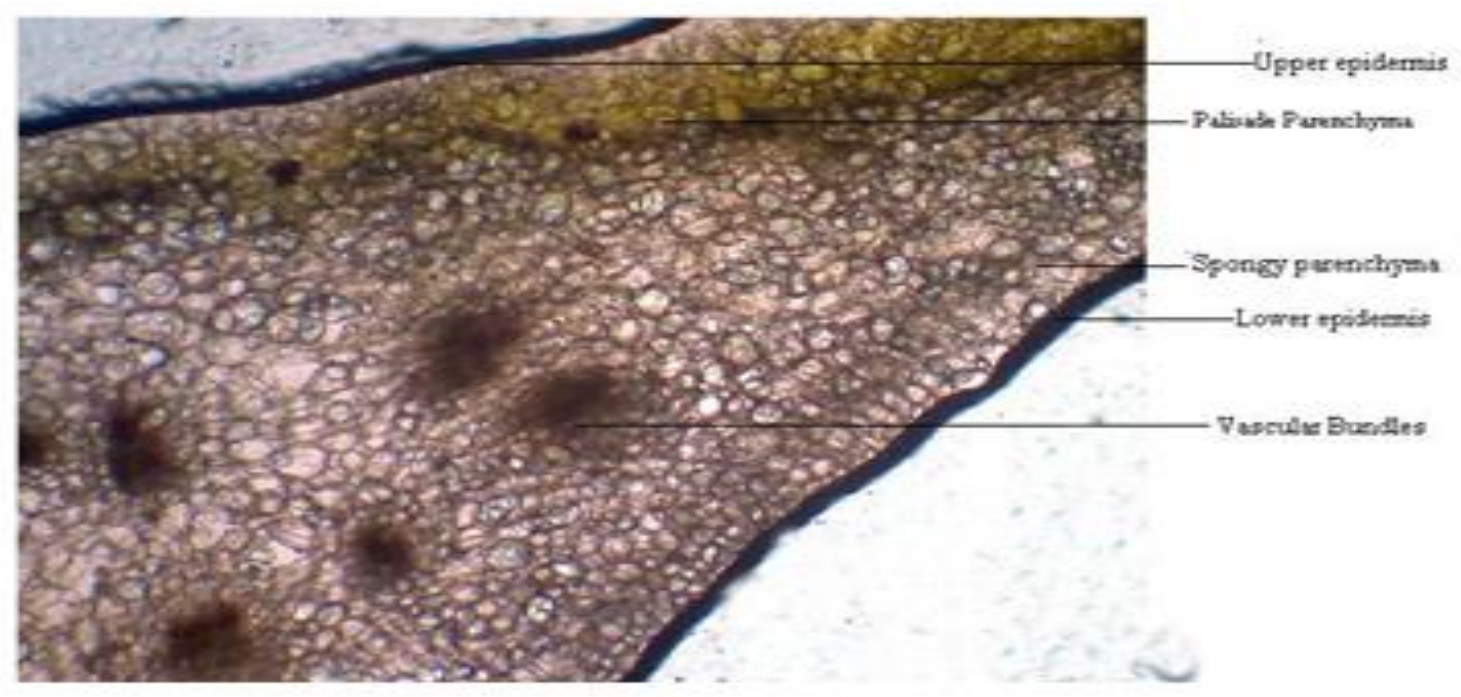

Figure 2. Transvers Section of leaf of $B$. ciliata

\section{Leaf surface feature}

The leaf surface study showed that $B$. ciliata was amphistomatic having anomocytic stomata on both upper and lower surfaces. The guard cells were $34 \mu$ and $10 \mu$ in average length and width and the stomatal pore was $26 \mu$ and $8 \mu$ (Figure 3 ). The mean \pm SEM of stomatal numbers of upper and lower epidermis was $(20 \pm 0.7)$ and (24.2 \pm
2.7) while stomatal index was $(15.6 \pm 2.6)$ and $27.4 \pm 3.9$ ) respectively (Figure 3 and Table 3). The vein islet and vein termination number was $(20.6 \pm 4.09)$ and $(26.6 \pm 5.01)$. The palisade ratio which is the average number of palisade cells beneath four upper epidermal cells was calculated as (12.3 \pm 3.71) (Table 3) 


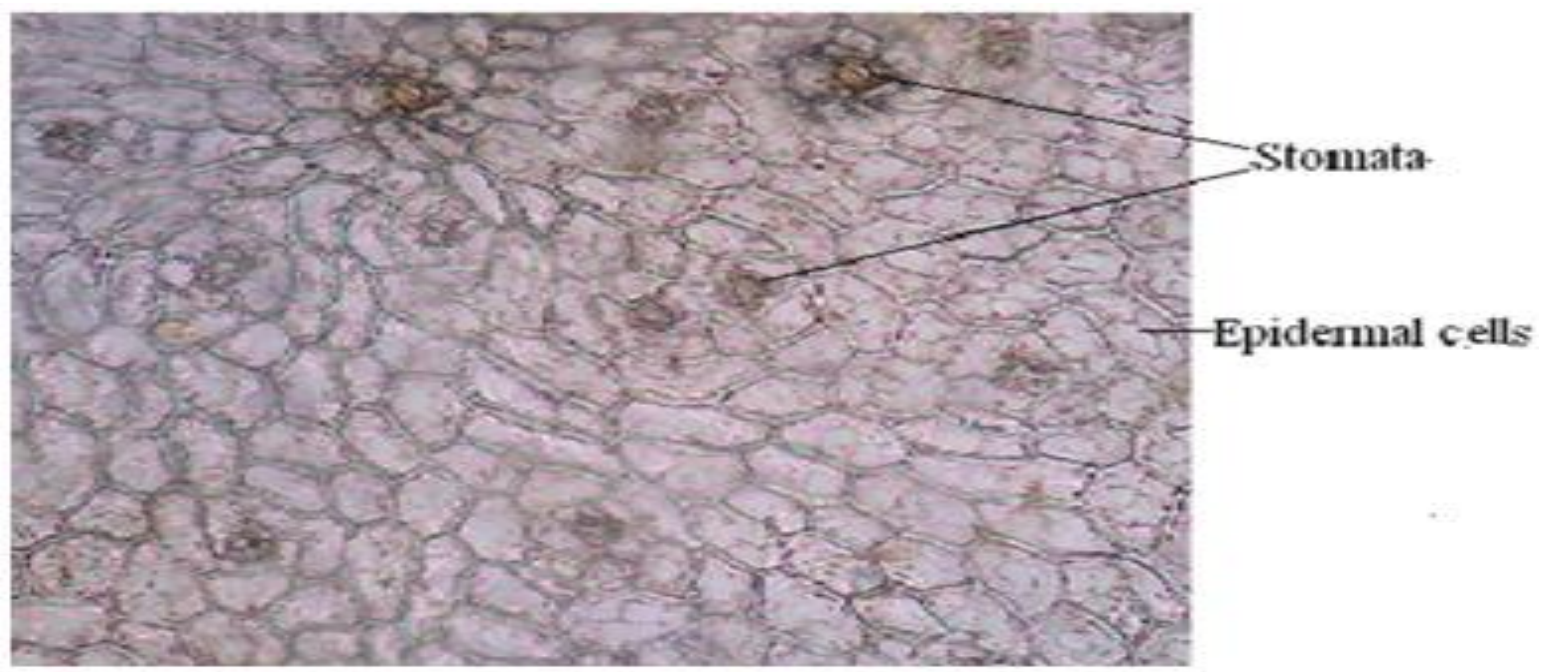

Figure 3. Upper epidermis of leaf showing anomocytic stomata

Table 3. Leaf surface data of the $B$. ciliate

\begin{tabular}{|c|l|c|c|}
\hline S.No & \multicolumn{1}{|c|}{ Leaf surface data } & Range & Mean \pm SEM \\
\hline $\mathbf{1}$ & Stomatal number Upper Epidermis & $10-28$ & $20 \pm 0.7$ \\
\hline $\mathbf{2}$ & Stomatal number Lower Epidermis & $13-31$ & $24.2 \pm 2.7$ \\
\hline $\mathbf{3}$ & Stomatal Index of Upper Epidermis & $19-34$ & $15.6 \pm 2.6$ \\
\hline $\mathbf{4}$ & Stomatal Index of Lower Epidermis & $8.9-27.5$ & $27.4 \pm 3.9$ \\
\hline $\mathbf{5}$ & Vein Islet Number & $10-25$ & $20.6 \pm 4.09$ \\
\hline $\mathbf{6}$ & Vein Termination Number & $7-19$ & $26.6 \pm 5.01$ \\
\hline $\mathbf{7}$ & Palisade Ratio ( Lower Epidermis) & $8-21$ & $12 \pm 3.71$ \\
\hline
\end{tabular}

\section{SEM of the powder drug of $B$. ciliata}

The powder drug study of B. ciliata through SEM was observed which showed that rhizome powder was dark brown in color with astringent taste and agreeable odor. The leaf powder appears dark green in color with indistinct odor and taste. The Scanning Electron Microscopy of rhizome showed following types of tissues

i) Fragments of parenchyma region with average cell length and width $33 \mu$ and $20 \mu$ (Table 4, Figure 4),

ii) Star shaped trichomes with mean length and width $250 \mu$ and $40 \mu$ (Table 4, Figure 5 and 6).

iii) Cluster of calcium oxalate crystals with each crystal having $26 \mu$ and $11 \mu$ average length and width (Table 4, Figure 7).
The scanning electron microscopy of leaf showed following types of tissues

i) Various types of non-glandular trichomes i.e tree shaped trichome with average length and width $350 \mu$ and $40 \mu$, simple uniseriate straight trichomes $(390 \mu$ and $74 \mu)$ and star shaped trichome $(350 \mu$ and $40 \mu$ ) respectively (Table 4 , Figure $6,8 a$ and $8 b$ ).

ii) Fragments of upper epidermis with anomocytic stomata with $39 \mu$ and $20 \mu$ and lower epidermis with $40 \mu$ and $23 \mu$ (Table 4, Figures 9a, 9b and 10a 10b),

iii) Spirally arranged phloem vessels having $28 \mu$ and $11 \mu$ length and width respectively (Table 4 and Figure 11) 
Table 4. SEM measurements ( $\mu$ ) of various tissues of Bergenia ciliata (Haw.) Sternb

\begin{tabular}{|c|c|c|c|c|c|c|c|c|c|c|c|c|}
\hline Plant parts & \multicolumn{7}{|c|}{ Anatomical features } & & & & & \\
\hline \multirow{3}{*}{ Rhizome } & \multicolumn{2}{|c|}{ Stellate trichomes } & \multicolumn{3}{|c|}{ Calcium oxalate Crystals } & \multicolumn{2}{|c|}{ Parenchyma tissues } & & & & & \\
\hline & Length & Width & Length & Width & & Length & Width & & & & & \\
\hline & $250 \mu$ & $40 \mu$ & $26 \mu$ & $11 \mu$ & & $33 \mu$ & $20 \mu$ & & & & & \\
\hline \multirow{3}{*}{ Leaf } & \multicolumn{2}{|c|}{ Stellate Trichome } & \multicolumn{2}{|c|}{ Simple Trichome } & \multicolumn{2}{|c|}{$\begin{array}{ll}\begin{array}{l}\text { Tree } \\
\text { trichome }\end{array} & \text { shaped } \\
\end{array}$} & \multicolumn{2}{|c|}{ Xylem Vessels } & \multicolumn{2}{|c|}{$\begin{array}{l}\text { Upper } \\
\text { Epidermal cells }\end{array}$} & \multicolumn{2}{|c|}{ Lower Epidermis } \\
\hline & Length & Width & Length & Width & Length & Width & Length & Width & Length & Width & Length & Width \\
\hline & $450 \mu$ & $50 \mu$ & $350 \mu$ & $74 \mu$ & $350 \mu$ & $4 \mathrm{~S} 0 \mu$ & $28 \mu$ & $11 \mu$ & $39 \mu$ & $20 \mu$ & $40 \mu$ & $23 \mu$ \\
\hline
\end{tabular}


Figure 4 and 5. Parenchyma cells and trichome in rhizome of Bergenia ciliate (Haw) Sternb 
Khan et al.

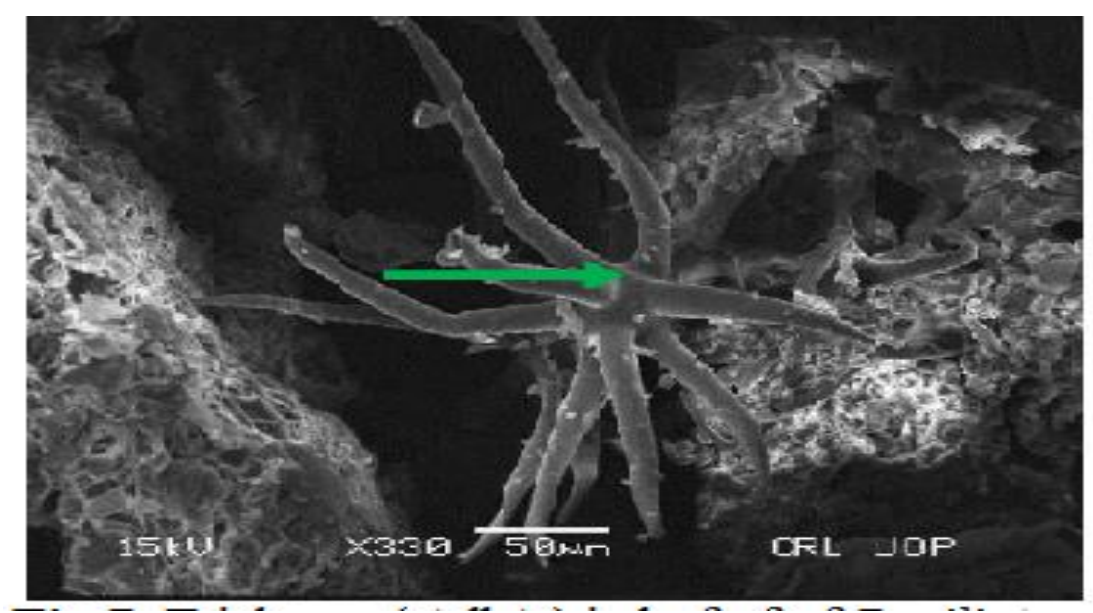

Figure 6. Trichome (stellate) in leaf of B. ciliate

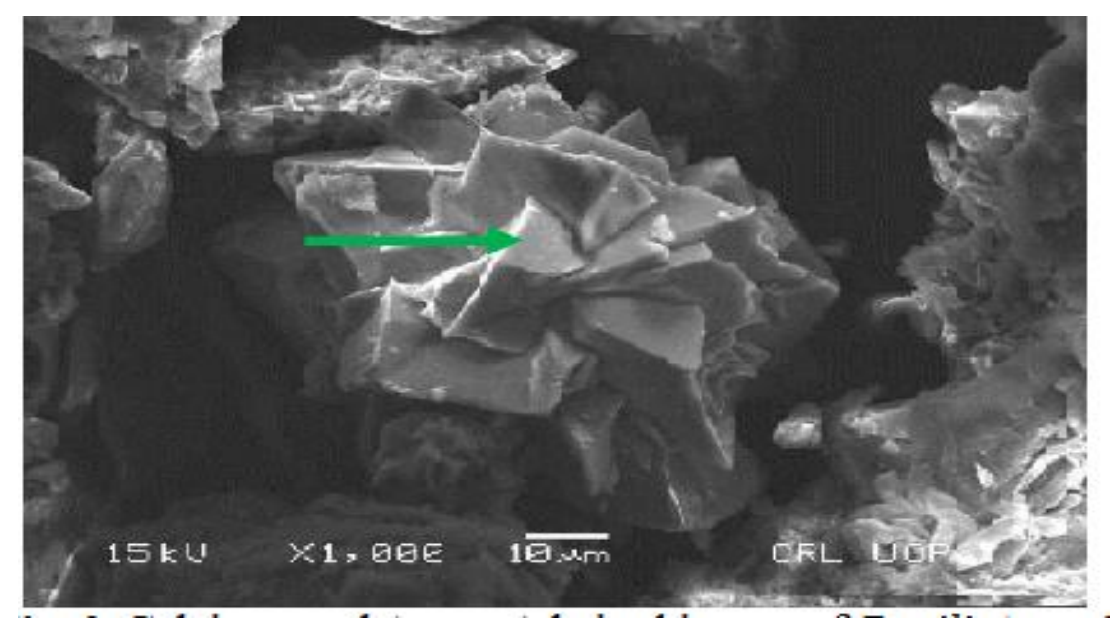

Figure 7. Calcium oxalate crystals in rhizome $B$. ciliate
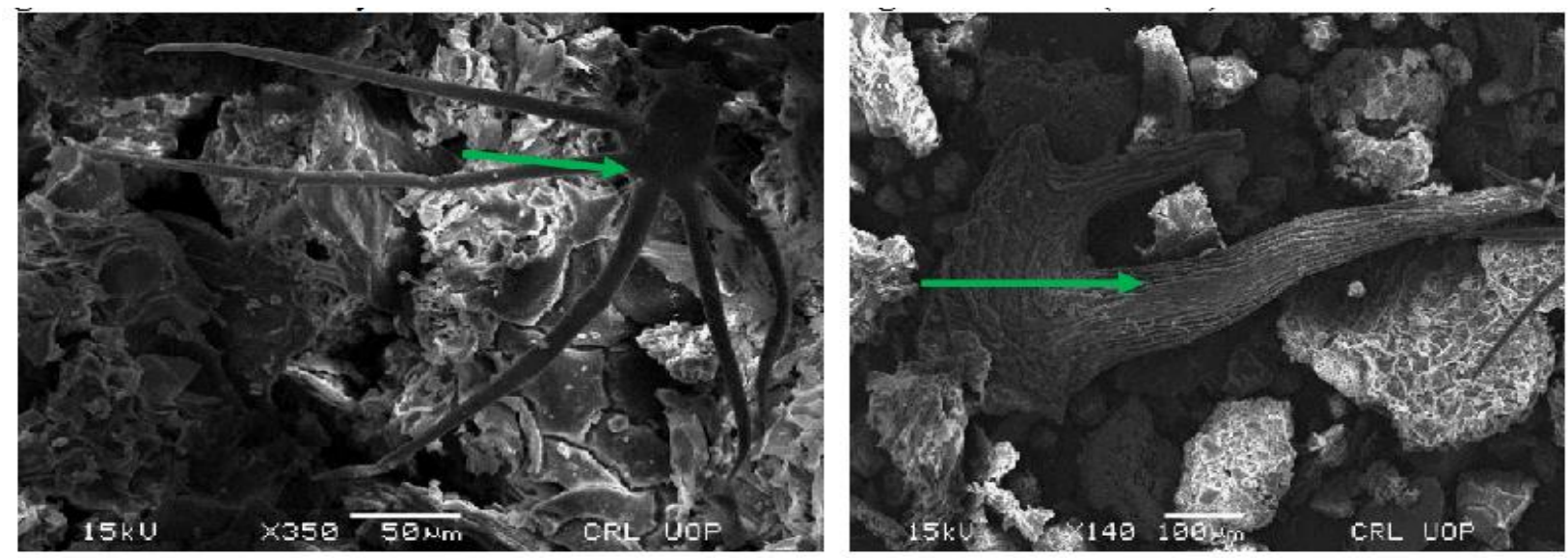

Figure 8a and 8b. Trichomes in leaf of Bergenia ciliate (Haw.) Sternb 



Figure 9a and 9b. Epidermis with stomata in leaf of Bergenia ciliate (Haw.) Sternb
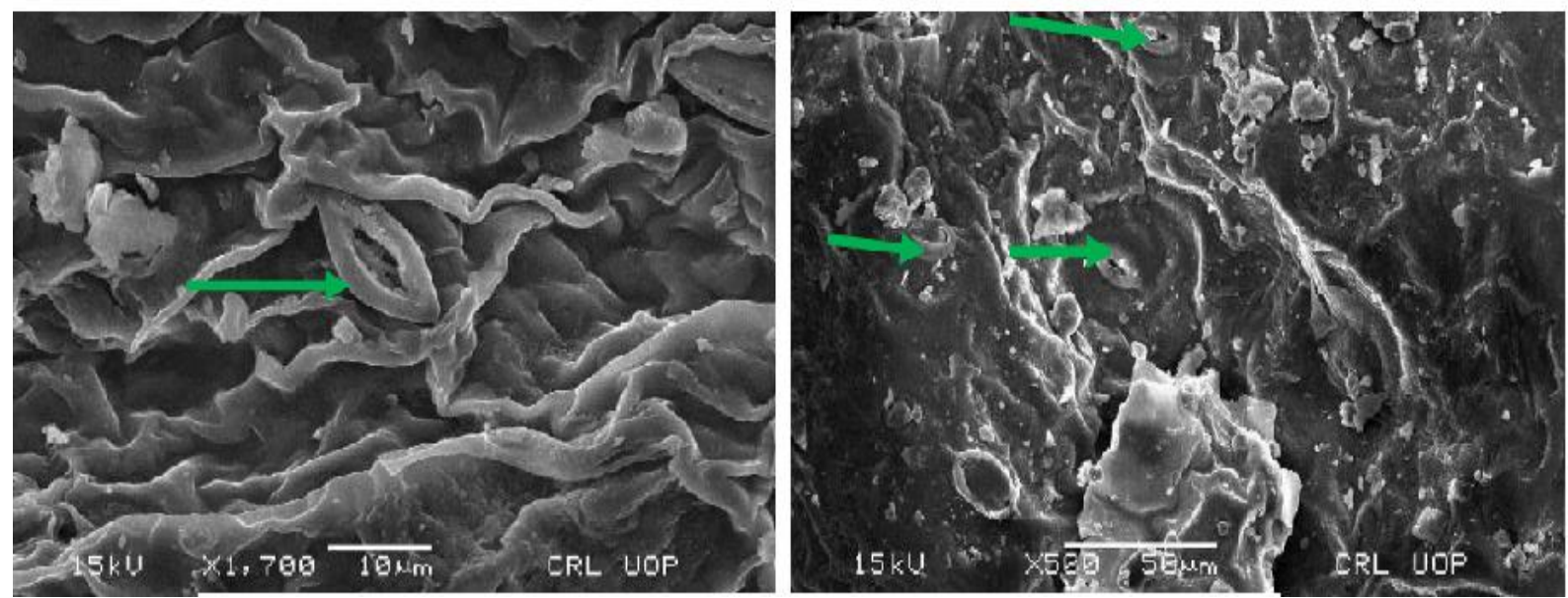

Figure 10a and 10b. Epidermis with stomata in leaf of Bergenia ciliate (Haw.) Sternb

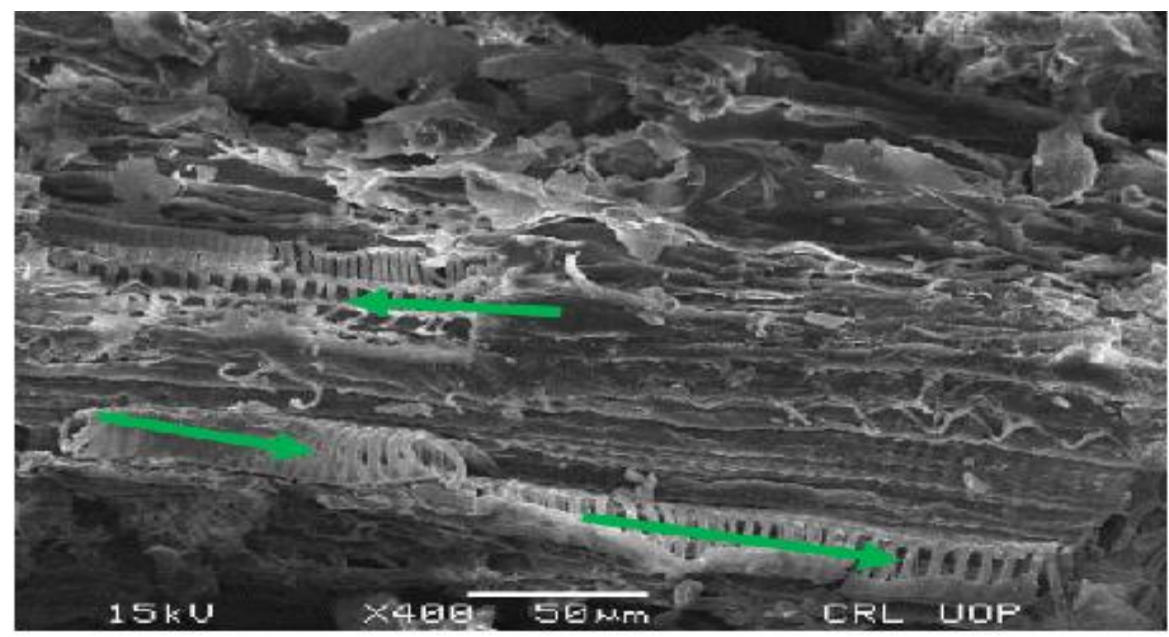

Figure 11. Vessel cells in leaf of Bergenia ciliate (Haw.) Sternb

\section{Fluorescence analysis}

The powder of rhizome and leaf of Bergenia ciliata showed several shades of colours from black to brown, yellow, green, dark blue, pink red etc when dipped and dissolved in various chemicals like $\mathrm{HCl}$, 
FeCl3, iodine, Nitric acid, Sulphuric acids and water etc and observed under ordinary and UV short (254nm) and long (366nm) wavelength, which was clear signal of the existence of various types of chemical substances. Results are shown in Table 5.

Table 5. Fluorescence analysis of different parts of $B$. ciliata (Haw.) Sternb

\begin{tabular}{|c|c|c|c|c|c|c|c|}
\hline S.No & Plant parts & \multicolumn{3}{|c|}{ Rhizome } & \multicolumn{3}{|c|}{ Leaf } \\
\hline & Reagent Used & $\begin{array}{l}\text { Day } \\
\text { light }\end{array}$ & $\begin{array}{l}\text { UV Low } \\
(255)\end{array}$ & $\begin{array}{l}\text { UV High } \\
\text { (366) }\end{array}$ & Day light & $\begin{array}{l}\text { UV Low } \\
(255)\end{array}$ & $\begin{array}{l}\text { UV High } \\
\text { (366) }\end{array}$ \\
\hline 1 & Iodine & $\mathrm{B}$ & Br.B & C.B & G & $\mathrm{Br}$ & $\mathrm{Br}$ \\
\hline 2 & Picric acid & D.Y & $\mathrm{Br}$ & $\mathrm{B}$ & $\mathrm{Y}$ & $\mathrm{Gr}$ & $\mathrm{B}$ \\
\hline 3 & Chrolroform & $\mathrm{Br}$ & B & B & G & $\mathrm{Gr}$ & D.B \\
\hline 4 & Ferric chloride & D.Br & B & C.B & $\mathrm{G}$ & D.Gr & D.B \\
\hline 5 & Ether & D.B & $\mathrm{Br}$ & D.Br & $\mathrm{G}$ & D.G & $\mathrm{Br}$ \\
\hline 6 & Ethanol & B & L.B & D.B & $\mathrm{G}$ & $\mathrm{Gr}$ & B \\
\hline 7 & $\mathrm{HCL}$ & $\mathrm{Br}$ & D.Br & D.B & $\mathrm{G}$ & D.G & $\mathrm{B}$ \\
\hline 8 & Acetic acid & $\mathrm{P}$ & $\mathrm{R}$ & $\mathrm{Br}$ & $\mathrm{P}$ & D.P & D.B \\
\hline 9 & $\mathrm{H}_{2} \mathrm{SO}_{4}$ & $\operatorname{Re}$ & $\mathrm{R}$ & $\mathrm{Br}$ & $\mathrm{Gr}$ & $\mathrm{B}$ & D.B \\
\hline 10 & $\mathrm{HNO}_{3}$ & $\mathrm{Br}$ & D.Br & $\mathrm{B}$ & L.G & D.G & $\mathrm{Br}$ \\
\hline 11 & Butanol & D.Br & $\mathrm{B}$ & D.B & $\mathrm{G}$ & $\mathrm{B}$ & $\mathrm{B}$ \\
\hline
\end{tabular}

Keys: $\mathrm{B}=\mathrm{Black}, \mathrm{Br}=$ Brown, $\mathrm{Cr}=$ Creamy, $\mathrm{D}=$ Dark, $\mathrm{G}=$ Green, $\mathrm{Gr}=$ Gray, L=Light, $\mathrm{P}=\mathrm{Pink}, \mathrm{R}=\mathrm{Red}, \mathrm{Y}=\mathrm{Yellow}$, $\mathrm{DL}=$ Day light, $\mathrm{SWL}=$ Short wavelength, $\mathrm{LWL}=$ Long wavelength

\section{Discussion}

\section{Macroscopical observation}

Macroscopic and organoleptic (sensory) evaluations are the main features in standardization and identification of crude natural drugs and the only parameters that required no involvement of scientific instruments neither any expenses. It gives a valuable, simplest, quickest and easiest information regarding purity and quality for recognition of adulterants in crude drugs $[19,20]$. The present work was conducted for the first time on $B$. ciliata, which will be helpful for the correct identification and authentication of crude drug available in herbal market. Several other researchers also carried out similar research work on various other medicinal plant and documented similar observation which are in line with the present work and strongly agree with this work [21- 24].

\section{Microscopical observations}

Microscopical observations include anatomical studies, powder drug studies and leaf constants like vein islets Number, vein termination number, occurrence and types of stomata, stomatal index and palisade ratio etc. Histological and anatomical study which provide help to plant taxonomist and will be used as a valuable source in plant systematics for differentiation between intraspecific and co-generic species of the same family for correct identification [25]. In pharmacognosy microscopic evaluation provide a tool for correct standardization, authentication, and identification of crude form of drugs $[22,26]$. The microscopical studies is done by numerous workers on large number of medicinal plants and explore its anatomy, leaf surface features, etc. and support our present work. [27-31].

\section{Leaf surface feature}

The leaf surface quantitative study like stomatal number, stomatal index, vein islet, vein termination number and palisade ratio provide a primary tool for differentiation between various leafy drugs belonging to same and related families [32]. Several other investigators [33-35] have studied leaf surface features of Mimosa pudica, Allium 
sativum, Verbascum thapsus, Heterophragma adenophylum, Holoptelea integrifolia, and Zizyphus mouritiana respectively and recommended the leaf surface and constant features as an important parameter for pharmacognostic and taxonomic fields. Several other workers [30, 36-38] also stress on stomata study to be a used in plant taxonomy to differentiate between closely related specie. The present quantitative work on $B$. ciliata will be provide an important knowledge to pharmacognosists and plant taxonomist on future.

\section{Powder drug study using SEM}

Most of the plant obtain drugs are available in market in powder form and sold in the raw form for curing of various disease and also as a main source of synthetic and natural medicines. So most of the powders of several plants are similar in physical appearance and also most of Hakeem and practitioners mix various economic crude drugs with high value drugs. Hence the powder drug study will provide help in identification of pure and specific drugs and also help in detection of adulteration [37]. Similar worked was done on several medicinal plants $[29,30,38]$.

\section{Fluorescence analysis}

Similarly, [39, 40] reported that fluorescence is important to observe all materials on reaction with different chemical reagents under UV light. According to [41] fluorescence is important to detect the presence of phytoconstituents in powder. $[39,42]$ studied the powder of leaf and young stem of Memecylon umbellatum shows variation colour under day light, short wavelength UV and long wavelength UV light treated with different chemical showed the presence of fluorescence compound. [43] reported that fluorescence can be used as diagnostic tool for testing adulteration if any can be easily identified [44] reported that fluorescence study is an essential parameter for first line standardization of crude drug. $[33,45]$ investigated the fluorescence characters of powdered of Portulaca quadrifida L. treated with different chemical reagents

\section{Conclusion}

From the present study it can be concluded that, B. ciliata is a perennial herb distributed in moist temperate regions of Pakistan like Shangla Swat, Gilgit Baltistan. Medicinally it is an Ayurvedic plant and used as astringent, tonic, laxative and in stomach and kidney problem especially in kidney. The present pharmacognostic standards like botanical description, microscopy, anatomy leaf surface features and fluorescence analysis could be useful for its correct identification and standardization and provide a base for its pharmacognistic implementations

\section{Authors' contributions}

Conceived and designed the experiments: SA Khan, Performed the Experiments: SA Khan \& G Dastagir, Analyzed the Data: Barkatullah \& I Ahmad, Contributed reagents/ materials/ analysis tools: U Ali, Wrote the paper: SA Khan \& S Ulllah.

\section{References}

1. Alluri V, Rao VN, Sundararaju D, Vanisree D, Tsay H \& Subbaraju GV (2012). Biological screening of medicinal plants collected from eastern ghats of India using Artemia salina (Brine Shrimp Test). Int J Appl Sci Eng 4 (2): 115-125.

2. Chitnis KS, Palekar SB, Koppar DR \& Mestry DY (2016). Evaluation of Syzygium cumini L. seed formulations available in the market using spectrophotometric and chromatographic techniques. Int J Pharm Sci Res 3(2): 556-560.

3. Karthikeyan R, Venkatesh P \& Chandrasekhar N (2013). Morpho anatomical studies of leaves of Abutilon indicum (L.) sweet. Asia Pacific J Trop Biomed 6(2): 464-469. 
4. Shweta S, Ganesh \& Somshekhar K (2015).

Morpho-anatomy,

Physicochemical and Phytochemical standardization with HPTLC fingerprinting of aerial parts of Rivea hypocrateriformis. Asia Pacif J Trop Biomed 22(1): 689-694.

5. Mbwambo ZH, Moshi MJ, Masimba PJ, Kapingu MC \& Nondo RSO (2015). Antimicrobial activity and brine shrimp toxicity of extracts of Terminalia brownii roots and stem. BMC Compl Altern Med 7(9): 7-9.

6. McLaughlin JL, Chang CL \& Smith DL (2014). Simple bench-top bioassays (brine-shrimp and potato discs) for the discovery of antitumour compounds. In: Human Medicinal Agents from Plants. (Eds.): A.D. Kinghorn and M.F. Balandrin. Washington DC: American Chemical Society pp. 112-137.

7. Soni H, Nayak G, Patel SS, Mishra K, Singh RP \& Singhai AK (2016). Pharmacognostic Studies of the Leaves of Tinospora Cordifolia. J Pharm Her Formul 1(3): 1-6.

8. Sutar N \& Garai R (2013). Pharmacognostical studies of Coccinia indica Wight \& Arn leaves. Int J Pharm Res Dev 2(10): 15-24.

9. Tehseen S, Afzal Z, Tasleem A, Bader GN, Mohammad N \& Shakir A (2015). Antibacterial and anti-inflammatory potential Bergenia ligulata. Am J Biomed Sci 2(4): 313-321.

10. Árok R, Végh K, Alberti A \& Kéry A (2014). Phytochemical comparison and analysis of Bergenia crassifolia $L$. and Bergenia cordifolia Sternb. Eur Chem Bull 1(1-2): 31-34.

11. Arya KR \& Prakash A (2014). Ethnomedicinal study of remote tribal areas of Almora district: a survey report. $J$ Econ Taxon Bot 23(2): 247-252.

12. Tamiljothi E, Ravichandiran V, Chandrasekhar N \& Suba V (2014).
Pharmacognostic and preliminary phytochemical screening of leaves of Tecomaria capensis. Asian J Plant Sci Res 1(3): 34-40.

13. Ghimare B, Ghimare BK \& Heo K (2014). Anotomy of the vegetative parts of Bergenia cillata (Haw.) Sternb. A potential medicinal herb. Int J Bot 8(3): 136-144.

14. Gupta PC \& Rao CV (2016). Morphoanatomical and physicochemical studies of Fumaria indica (Hausskn.) Pugsley. Asia Paci J Trop Biomed 23(6): 830834.

15. Gupta PC, Sharma N \& Rao CV (2015). Pharmacognostic studies of the leaves and stem of Careya arborea Roxb. Asian Paci J Trop Biomed 6(2): 404408.

16. Idu M, Erhabor JO \& Odia EA (2013). Morphological and anatomical studies of the leaf and stem of some medicinal plants: Stachytarpheta jamaicensis (L.) Vahl. and S. cayennensis (L.C.Rich). Ethnobot Leaflets 13:1417-25

17. Islam M, Azhar I, Mazhar F, Usmanghani F, Gill MA, Ahmad A \& Shahab-Ud-Din (2015). Evaluation of antibacterial activity of Bergenia ciliata. Pak J Pharma Sci 15(2): 21-27.

18. Modi DC, Patel JK, Shah BN \& Nayak BS (2014). Pharmacognostic studies of the seed of syzygium cumini L. Int $J$ Pharma Sci 1(1): 20-26.

19. Jain PK, Soni P, Upmanyu N \& Shivhare Y (2014). Evaluation of Analgesic Activity of Manilkara Zapota (Leaves). Eur J Exp Bio 1 (1):14-17.

20. Juliet S, Jothi S \& Rajakumar TJS (2015). Pharmacognostic standardisation of didymocarpus tomentosus (Gesneriaceae). Int J Pharm Pharm Sci 4(2): 975-1491.

21. Kadam P, Yadav VKN, Deoda RS, Narappanawar NS, Shivatare RS \& Patil MJ (2015). Pharmacognostic and 
phytochemical studies on roots of Agave Americana (Agavaceae). Int $J$ Pharmacog Phytochem Res 4(3): 92-96.

22. Ashotosh K (2015). Pharmacognosy and pharmacoboitechnology (Revisedexpended $2^{\text {nd }}$ ed). New age international (P) limited publishers pp: 3-5.

23. Biswal Bl, Saha SD, Beura S, Jana SB, Koley A, Sur D \& Mohanty JC (2015). Pharmacognostic Studies of Leaves of Derris Indica. Int J Res Pharma Biomed Sci 2(1): 294-297.

24. Chand T, Bhandari A, Kumawat BK, Sharma A, Bansa VK \& Pareek A (2014). Phytochemical investigation of seed of Cucumis callosus (Rottl.) Cogn. Res J Pharma Biol Chem Sci 3(2): 570576.

25. Madhavan V, Goswami P, Gurudeva MR \& Yoganarasimhan SN (2014). Pharmacognostical studies on the root of Nothosaerva brachiata Wt. A botanical source of the Ayurvedic drug Pashanabheda. Ind J Trad Know 9(4): 629-634.

26. Manjunatha SN (2016). Pharmacognostic pringer print profile of a controvertial drug Paashanbheda. Department of pharmacognosy P.E.S College of pharmacy Banglore 1-3.

27. Chandra S, Kumar V, Bandopadhya R \& Sharma MM (2015). SEM and elemental studies of Swertia chirayita: a critically endangered medicinal herb of temperate Himalayas. Curr Tr Biotech Pharm 6(3): 373-380.

28. Chulet R, Joseph L, George M \& Pradhan P (2013). Pharmacognostic standardization and phytochemical screening of Albizzia lebbeck. J Chem Pharm Res 2(1): 432- 443.

29. Kalakoti BS \& Pangtey YP (2015). Quantitative analysis of high altitude vegetation of Kumaun Himalaya. J India Bot Sci 65: 384-396.
30. Kumar D, Kumar K, Kumar S, Kumar T, Kumar A \& Prakash O (2014). Pharmacognostic evaluation of leaf and root bark of Holoptelea integrifolia Roxb. Asian Pac J Trop Biomed 4(5): 169-175.

31. Biradar YS \& Mahadik KR (2016). Simultaneous quantification of bergenin, catechin and gallic acid from Bergenia ciliata and Bergenia ligulata by using thin-layer chromatography. $J$ Food Comp Ana 6(2): 496-500.

32. Mir MA, Sawhney SS \& Jassal MMS (2013). Qualitative and quantitative analysis of phytochemicals of Taraxacum officinale. Wudpecker J Phar Pharmocol 2(1): 1 -5.

33. Mulla SK \& Swamy S (2015). Preliminary pharmacognostical and phytochemical evaluation of Portulaca quadrifida Linn. Int J Pharm Tech 2(3): 1699-1702.

34. Okhale, Ehiabhi S, Amanabo M, Omachonu I, Adeola S, Egharevba H, Omoregie I, Muazzam IW, Kunle O \& Folashade O (2013). Phytochemical and pharmacognostic investigation of Antidiabetic Scoparia dulcis L. Scrophulariaceae whole plant Grown in Nigeria. Int J Pharm Inno 2(6): 313-321.

35. Padmavathy J, Raju D, Saraswathi VS, Kayalvizhi M \& Saravanan D (2013). Pharmacognostic parameters for the evaluation of the leaves and loung stem of Memecylon umbellatum Burm. Int J Pharm Tech Res 2(3): 2001-2006.

36. Paul S, Saha D \& Chowdhury S (2014). Pharmacognostic studies on aerial parts of methanolic extract of Mimosa pudica. Asian J Pharm Tech 2(3): 101 - 103.

37. Rakholiya K \& Chanda S (2012). Pharmacognostic, Physicochemical and phytochemical investigation of Mangifera indica L. var. Kesar leaf. Asia Pac J Trop Biomed 22(4): 680-684. 
38. Ruby KM, Dwivedi J \& Chauhan K (2014). Pashanbheda a golden herb of Himalaya: a review. Int J Pharm Rev Res 2(2): 97-105.

39. Sharma SK \& Kumar N (2012). Pharmacognostical evaluation of the rhizomes of Picrorhiza kurroa Royle Ex Benth. J Pharm Res 5(2):1116-1118.

40. Umashankar DCR, Chawla AS, Deepak M, Singh D \& Handa SS (2016). High pressure liquid chromatographic determination of bergenin and ( + ) afzelechin from different parts of Paashaanbhed (Bergenia ligulata Yeo). Phytochem Ana 10(1): 44-47.

41. Wallis TE (2009). A Textbook of Pharmacognosy. ( $5^{\text {th }}$ Ed.) National Book Foundation, Islamabad. pp: 322-331.

42. Youngken HW (2006). A
Pharmacognostical Study of Root of
Different species of Veratrum. J Amer Pharmaceut Ass 9(11): 112-121.

43. Zheng R, Yan-ying $\mathrm{Y} \&$ Shu-wen (2009). Research progresses on chemical constituents of genus Bergenia and their bioactivities. J Med Pl Res 3(9): 249255.

44. Ravikumar S, Ashokkumar S, Mallika K, Kabilar P, Paneerselvam P \& Gayathri M (2011). Morphological, micro and macro nutrient analysis of the medicinal plant glory lily (Gloriosa superba L.). J Experim Sci 2(6): 04-06.

45. Reader VA (2015). Pharmacognosy, principles of classification of plants. Faculty of Pharmacy Jamia Hamdard Hamdard Nagar New Delhi-110062. pp.2-5. 